\title{
Teaching Video NeuroImage: Resolution of Ptosis After Forceful Eye Closure
}

Bedside Diagnosis of Myasthenia Gravis

Vasiliki Zouvelou, MD, PhD, and Ariadne Daponte, MD

Neurology ${ }^{\circledR}$ 2021;97:e649-e650. doi:10.1212/WNL.0000000000012100

Figure Bienfang Test

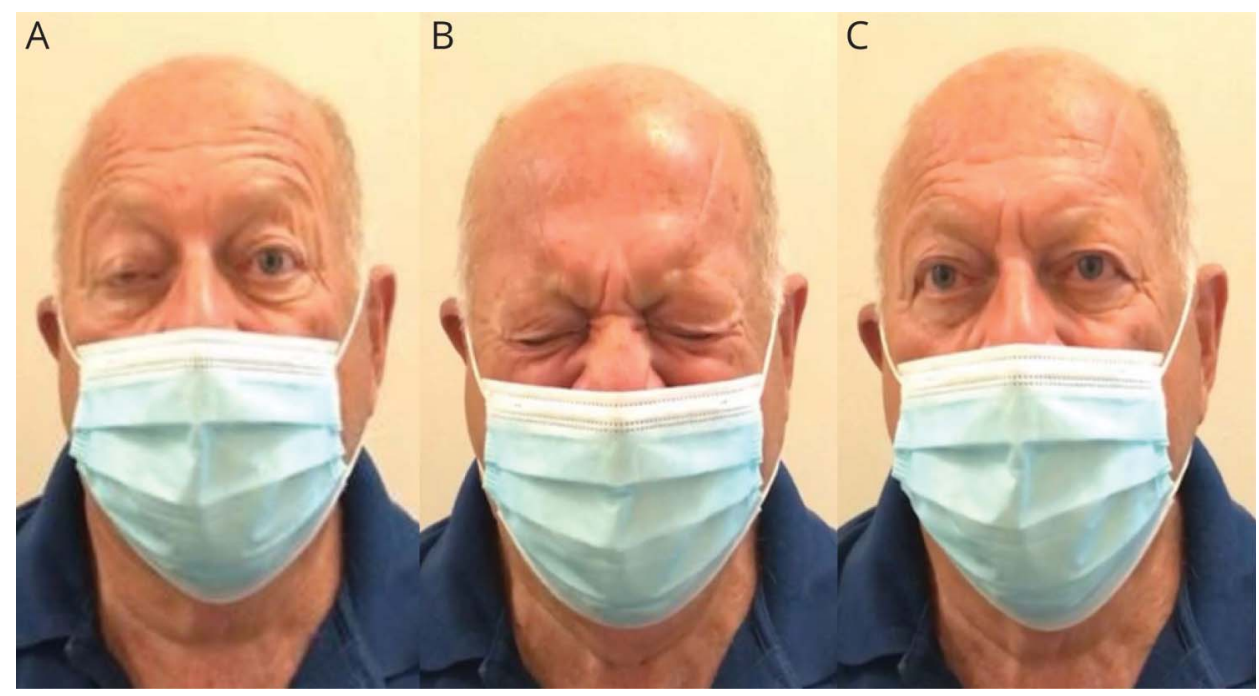

Fatigable eyelid ptosis (A), forceful eye closure (B), and resolution of ptosis (C).

A 72-year-old man presented with fluctuating right eyelid ptosis. During sustained gaze fixation without blinking, the blepharoptosis progressively increased to almost complete ptosis, because of fatigable weakness of the levator palbebrae superioris (LPS) muscle. Noticeable is the eyebrow lifting due to compensatory frontalis muscle contraction (figure). The patient was asked to close his eyes forcefully for 30 seconds (Bienfang test) (figure). Immediately the ptosis resolved (figure; video). During maximal voluntary contraction of the orbicularis oculi (OO), the antagonistic LPS is inhibited and relaxes. On eyelid opening, the LPS is fully recovered, while the OO is fatigued. The sensitivity and specificity of the Bienfang test is $94 \%$ and $91 \%$, respectively. ${ }^{1,2}$ The diagnosis was acetylcholine receptor-positive ocular myasthenia gravis.

\section{Study Funding}

No targeted funding reported.

\section{Disclosure}

The authors have nothing to disclose. Go to Neurology.org/ $\mathrm{N}$ for full disclosures.
Correspondence

Dr. Zouvelou

vzouvelu@med.uoa.gr

\section{MORE ONLINE}

\section{Video}

\section{Teaching slides}

links.lww.com/WNL/

B395 


\section{Appendix Authors}

\begin{tabular}{lll}
\hline Name & Location & Contribution \\
\hline $\begin{array}{l}\text { Vasiliki } \\
\text { Mouvelou, PhD }\end{array}$ & $\begin{array}{l}\text { 1st Neurology Department, } \\
\text { Eginition Hospital, National and } \\
\text { Kapodistrian University of } \\
\text { Athens, Greece }\end{array}$ & $\begin{array}{l}\text { Design of the study, } \\
\text { analysis and interpretation } \\
\text { of the data, drafting and } \\
\text { revising the manuscript, } \\
\text { multimedia files creation }\end{array}$ \\
\hline $\begin{array}{l}\text { Ariadne } \\
\text { Daponte, } \\
\text { MD }\end{array}$ & $\begin{array}{l}\text { 1st Neurology Department, } \\
\text { Eginition Hospital, National and } \\
\text { Kapodistrian University of } \\
\text { Athens, Greece }\end{array}$ & $\begin{array}{l}\text { Analysis and interpretation } \\
\text { of the data, revising the } \\
\text { manuscript, multimedia } \\
\text { files creation }\end{array}$ \\
\hline
\end{tabular}

\section{References}

1. Apinyawasisuk S, Zhou X, Tian JJ, Garcia GA, Karanjia R, Sadun AA. Validity of forced eyelid closure test: a novel clinical screening test for ocular myasthenia gravis J Neuroophthalmol. 2017;37(7):253-257.

2. Remington LA. Ocular andexa and lacrimal system. In: Clinical Anatomy and Physiology of the Visual System, 3rd ed. Butterworth-Heinemann: 2011;159-181. 


\section{Neurology}

\section{Teaching Video NeuroImage: Resolution of Ptosis After Forceful Eye Closure: Bedside Diagnosis of Myasthenia Gravis}

Vasiliki Zouvelou and Ariadne Daponte

Neurology 2021;97;e649-e650 Published Online before print April 30, 2021

DOI 10.1212/WNL.0000000000012100

This information is current as of April 30, 2021

Updated Information \&
Services

References

Subspecialty Collections

Permissions \& Licensing

Reprints including high resolution figures, can be found at: http://n.neurology.org/content/97/6/e649.full

This article cites 1 articles, 0 of which you can access for free at: http://n.neurology.org/content/97/6/e649.full\#ref-list-1

This article, along with others on similar topics, appears in the following collection(s):

Myasthenia

http://n.neurology.org/cgi/collection/myasthenia

Information about reproducing this article in parts (figures,tables) or in its entirety can be found online at:

http://www.neurology.org/about/about_the_journal\#permissions

Information about ordering reprints can be found online:

http://n.neurology.org/subscribers/advertise

Neurology ${ }^{\circledR}$ is the official journal of the American Academy of Neurology. Published continuously since 1951, it is now a weekly with 48 issues per year. Copyright (C 2021 American Academy of Neurology. All rights reserved. Print ISSN: 0028-3878. Online ISSN: 1526-632X.

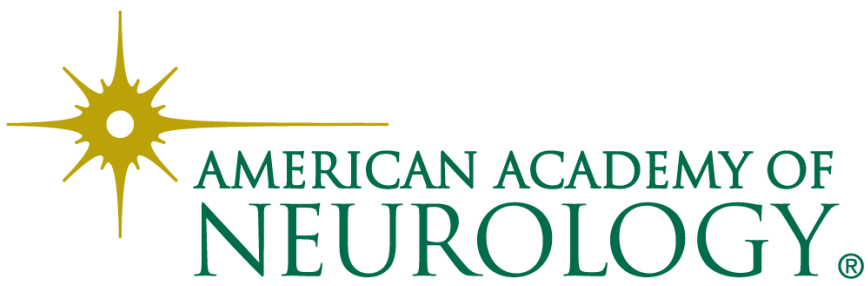

